\title{
Zbirka živih kultur Laboratorija za varstvo gozdov na Gozdarskem inštitutu Slovenije (ZLVG)
}

\section{Barbara PIŠKUR*}

Zbirka živih kultur Laboratorija za varstvo gozdov na Gozdarskem inštitutu Slovenije (v nadaljevanju ZLVG, ang. Culture Collection of the Laboratory of Forest Protection at the Slovenian Forestry Institute) je zbirka živih kultur fitopatogenih in drugih gliv. Je edina zbirka v Sloveniji, ki obsega predvsem tiste glive, ki povzročajo bolezni na lesnatih rastlinah. Zbirko smo v zdajšnji obliki zasnovali leta 2007, prvi vnos je bil izolat vrste Eutypella parasitica. Do avgusta 2014 smo v zbirko shranili 396 izolatov $^{1}$, ki predstavljajo 71 različnih taksonomskih enot - nekateri vnosi so namreč določeni le do nivoja rodu, večina vnosov pa je določena do vrstnega imena glive. Zbirka med drugim vsebuje obširen nabor izolatov vrst Chalara fraxinea (116 vnosov), Eutypella parasitica (70 vnosov) in Botryosphaeria dothidea (68 vnosov). Seznam ter podatke o shranjenih kulturah gliv od leta 2009 urejamo s pomočjo računalniške aplikacije Boletus informaticus .NET (slika 1; Ogris, 2008).

Za shranjevanje izolatov (živih kultur) v zbirki ZLVG uporabljamo metodo shranjevanja pod mineralnim oljem pri $4{ }^{\circ} \mathrm{C}$ (slika 2). Stanje shranjenih kultur preverjamo na letni ravni. Ravno tako enkrat letno preverjamo kultivabilnost naključno izbranih shranjenih izolatov. Uporabljena metoda shranjevanja ima prednosti (npr. obstojnost, cenovno ugoden način shranjevanja, majhna verjetnost namnožitev pršic) pa tudi določene pomanjkljivosti (npr. verjetnost kontaminacij, povečan selekcijski pritisk zaradi ekstremnih razmer, $\mathrm{v}$ katerih se shranjene glive nahajajo, zmanjševanje kultivabilnosti s časom shranjevanja) (Smith in Onions, 1994). Zato načrtujemo nadgraditev zbirke $\mathrm{z}$ različnimi načini shranjevanja, v kolikor bo to dopuščala finančna situacija. Duplikate pomembnejših izolatov shranjujemo v tujih zbirkah CBS (Zbirka kultur na Centraalbureau voor Schimmelcultures, Nizozemska) in CMW (Zbirka kultur na Forestry and Agricultural Biotechnology Institute, Južna Afrika).

Vsak izolat, ki ga shranimo v zbirko ZLVG, mora spremljati evidenčni list s podatki o zgodovini izolacije in identifikacije, morebitnih identifikacijskih številkah drugih zbirk in identifikacijske številke nukleotidnih zaporedij, v kolikor so znane. V zbirko namreč preferenčno shranjujemo izolate, katerim smo določili nukleotidno zaporedje vsaj ene genske regije (največkrat regija ITS rDNA, slika 3). Postopek shranjevanja v zbirko poteka centralno in ga izvaja odgovorna oseba za deponiranje izolatov (tehnična sodelavka Laboratorija za varstvo gozdov). Vsak shranjen izolat dobi identifikacijsko številko, ki je sestavljena iz oznake zbirke (ZLVG) in pripadajoče številke. Tako ima npr. prvi vnos v zbirko identifikacijsko številko ZLVG1, zadnji pa ZLVG396.

Zbirke so za učinkovito diagnostiko neobhodne, saj omogočajo primerjavo z referenčnimi vzorci in preverjanje pravilnosti identifikacije (Shivas in Beasley, 2005). So tudi dokazni material, na katerem sloni izvajanje fitosanitarnih ukrepov v primeru najdb karantenskih organizmov.

Zbirka ZLVG je nekomercionalna zbirka. Ker so določene glive na seznamu karantenskih škodljivih organizmov in so nevarni patogeni za rastline, je dostop do zbirke omejen le na pooblaščene sodelavce Laboratorija za varstvo gozdov.

$\mathrm{V}$ prihodnosti želimo nadaljevati z zbiranjem različnih izolatov gliv v zbirko ZLVG ter določiti zaporedje vsaj ene genske regije (ITS rDNA) vsem shranjenim izolatom. Zaradi strateškega pomena zbirke pa upamo, da bomo lahko zbirko nadgradili s sodobnejšimi načini shranjevanja ter tako omogočili varnejše in dolgotrajnejše ohranjanje nabora trajnih kultur.

${ }^{1} \mathrm{Z}$ izrazom »izolat (glive)« poimenujemo čiste micelijske kulture, ki smo jih izolirali iz populacije osebkov iz npr. rastlinskega tkiva. Izraz sev pa uporabljamo za izolat oziroma skupino izolatov, ki imajo znane fenotipske in/ali genotipske lastnosti, in se po omenjenih lastnostih ločijo od drugih izolatov iste taksonomske skupine.

\section{Viri}

Ogris N. 2008. Podatkovna zbirka gliv Slovenije Boletus informaticus. Računalniški program.

Shivas R., Beasley D. 2005. Management of plant pathogen collections. Canberra, Department of agriculture, fisheries and forestry: 82 str.

Smith D., Onions A.H.S. 1994. The preservation and maintenance of living fungi. IMI Technical Handbooks, No. 2. CAB International: 122. str.

*Gozdarski inštitut Slovenije, Večna pot 2, 1000 Ljubljana barbara.piskur@gozdis.si 


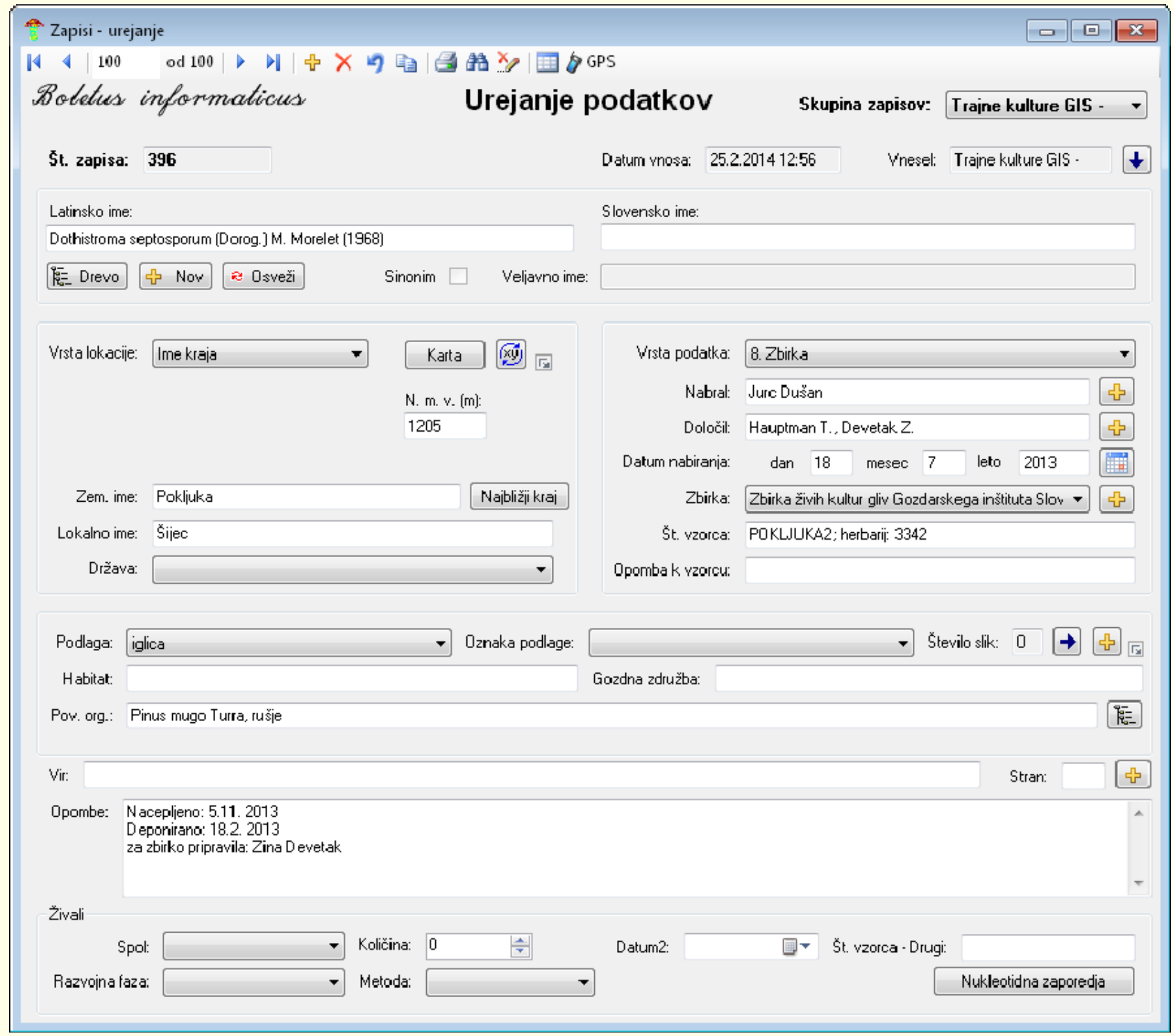

Slika 1: Primer zapisa v aplikaciji Boletus informaticus .NET 


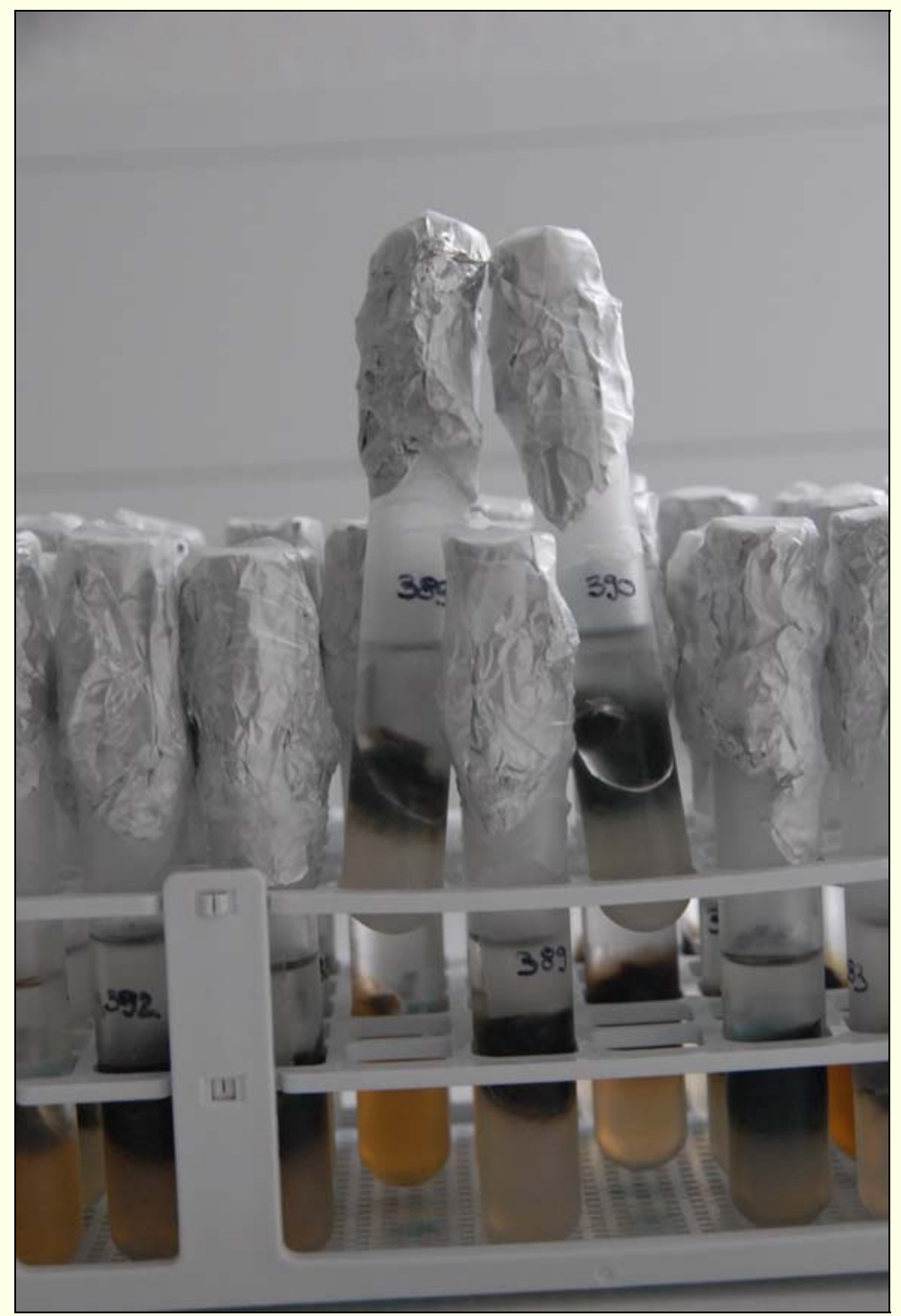

Slika 2: Shranjene micelijske kulture na poševniku in prekrite z mineralnim oljem

\begin{tabular}{|c|c|c|c|}
\hline \multicolumn{4}{|c|}{ Nukleotidna zaporedja } \\
\hline \multirow[t]{2}{*}{$14 \quad 4$} & 1 & od 3 & $\nu$ D Branje \& GenBank \\
\hline & Naziv & & št. \\
\hline \multirow[t]{3}{*}{ ' } & $E F-1 \alpha$ & & KC149566 \\
\hline & ITS & & KC149562 \\
\hline & Bt2 & & KC149570 \\
\hline
\end{tabular}

Slika 3: Iz glavnega zapisa (slika 1) lahko odpremo okno s podatki o pripadajočih nukleotidnih zaporedjih, ki smo jih shranili v mednarodno podatkovno bazo nukleotidnih zaporedij INSDC 